Quigley Alyssa (Orcid ID: 0000-0003-4758-5387)

Hutton Jennie (Orcid ID: 0000-0001-7911-9546)

Phillips Georgina (Orcid ID: 0000-0002-0414-2802)

\title{
Implicit bias towards Aboriginal and Torres Strait Islander patients within Australian Emergency
}

\section{Departments}

Running title: Implicit bias in Australian Emergency Departments

Alyssa Quigley BBiomedSc

Medical Student, Department of Medicine, University of Melbourne, Melbourne, Australia

Dr Jennie Hutton, MBChB MPH FACEM

Emergency Physician, St Vincent’s Hospital, Melbourne, Australia

Department of Medicine, University of Melbourne, Melbourne, Australia

Dr Georgina Phillips, MBBS FACEM

Emergency Physician, St Vincent's Hospital, Melbourne, Australia

PhD Scholar, School of Public Health and Preventive Medicine, Monash University, Melbourne, Australia

Darlene Dreise BEd MEd MLearnInnov

Chair, Reconciliation Action Plan (RAP) Steering Committee, St Vincent’s Health Australia

Toni Mason

Manager, Aboriginal Health Unit, St Vincent's Hospital Australia, Melbourne, Australia

Professor Gail Garvey BEd MEd PhD

Senior Principal Research Fellow, Menzies School of Health Research

Senior Aboriginal Research Fellow, St Vincent’s Health Australia

Professor Yin Paradies, BSc MMedStats MPH PhD

This is the author manuscript accepted for publication and has undergone full peer review but has not been through the copyediting, typesetting, pagination and proofreading process, which may lead to differences between this version and the Version of Record. Please cite this article as doi: $10.1111 / 1742-6723.13691$

This article is protected by copyright. All rights reserved. 
Corresponding author: Alyssa Quigley (ajquigley@student.unimelb.edu.au)

Medical Student, Department of Medicine, University of Melbourne, Melbourne, Australia

Competing interests: Dr Georgina Phillips is a section editor for Emergency Medicine Australasia

Author contribution statement: This paper was conceived by AQ and JH. Search and data extraction by AQ and JH.

Interpretation and write-up by AQ, JH, GP, DD, TM, GG and YP. All authors have approved the final version of this paper.

Keywords: Aboriginal and Torres Strait Islander peoples, Emergency, Implicit bias, Healthcare disparities, Racism

\section{ABSTRACT}

Aboriginal and Torres Strait Islander peoples continue to suffer adverse experiences in healthcare, with inequitable care prevalent in emergency settings. Individual, institutional and systemic factors play a significant part in these persisting healthcare disparities, with biases remaining entrenched in healthcare institutions. This includes implicit racial bias which can result in stereotyping of racial minorities and premature diagnostic closure. Furthermore, it may contribute to distrust of medical professionals resulting in higher rates of leave events and hinder racial minorities from seeking care or following treatment recommendations. The aim of this review is to analyse the effect of implicit bias on patient outcomes in the ED in international literature and explore how these studies correlate to an Australian context.

Keywords: Aboriginal and Torres Strait Islander peoples, Emergency, Implicit bias, Healthcare disparities, Racism

\section{INTRODUCTION}

The Emergency Department (ED) is often the first interaction that marginalised patient groups have with the healthcare system ${ }^{1}$. This includes those with an insecure living situation, poor mental health, substance use issues and racial or ethnic minority groups ${ }^{2}$. In Australia, Aboriginal and Torres Strait Islander people make up $3.3 \%$ of the population ${ }^{3}$ but are over-represented in presentations to the ED, 
accounting for $6.7 \%$ of presentations in $2018^{4}$. Historically they have been mistreated by healthcare institutions ${ }^{5}$ with inequitable care prevalent within emergency settings ${ }^{6}$.

Notable cases that highlight this inequity among Aboriginal and Torres Strait Islander people include Naomi Williams ${ }^{7}$, Charlie Gowa ${ }^{8}$ and $\mathrm{Ms} \mathrm{Dhu}^{9}$. Both Charlie Gowa and Naomi Williams had repeated ED presentations with inadequate care exposed on Coronial investigations. Racial stereotyping was found to be prominent in the case of Naomi Williams, with doctors attributing her unrelenting symptoms to drug use ${ }^{7}$. Similarly, heuristic thinking and 'premature diagnostic closure' ${ }^{9}$ occurred as a result of preconceived biases in the case of Ms Dhu. These cases illustrate the effects that implicit bias may have on clinical decision-making and healthcare outcomes ${ }^{10}$.

Implicit bias may be defined as negative attitudes that "exist outside of conscious awareness", thus influencing behaviour ${ }^{10}$. ED settings are suggested to have greater susceptibility to implicit bias due to a time-pressured environment where doctors may rely on pattern recognition to formulate diagnoses ${ }^{1}$. This can result in stereotyping of racial minorities ${ }^{11}$ leading to misdiagnosis ${ }^{12}$ and failure to tailor care to the individual. Furthermore, implicit bias may result in disparities in care ${ }^{13}$ of Indigenous people compared to their non-Indigenous counterpart.

International evidence illustrates how racial and ethnic groups experience disparities in triage scores $^{14}$, radiographic assessment ${ }^{15}$, coronary angiography ${ }^{16}$, surgical waiting times ${ }^{17}$ and analgesia recommendations ${ }^{18}$. Australian studies have shown that Indigenous Australians have a higher admission rate $^{19}$, greater severity of illness ${ }^{19}$, and higher burden of cardiometabolic comorbidities ${ }^{20}$. Additionally, Indigenous Australians have a reduced life expectancy and Australian Indigenous children have twice the 
mortality rate of non-Indigenous children ${ }^{21}$. These disparities indicate the ongoing impacts of colonisation and structural racism².

The aim of this review is to analyse the effect of implicit bias on patient outcomes in the ED. Existing literature relates primarily to international examples, but we will explore how these studies correlate to an Australian context.

\section{METHODS}

\section{Search Strategy}

A structured literature search of PubMed, Medline, CINAHL, Psycinfo, EMBASE and EMCARE was performed (appendix 1). Key words used were 1) “implicit bias” or “unconscious bias” or “unaware bias” 2) ED or emergency 3) racism or race or “covert racism” or "racial bias” or "racial discrimination” or "racial prejudice”.

\section{Inclusion \& Exclusion Criteria}

Two independent researchers screened the title and abstract of each article for suitability. Eligible studies were those published in English between 2005-2020 that measured implicit racial bias in ED healthcare workers. Additional studies that met the inclusion criteria were those that were based upon an emergency vignette. Other exclusion criteria included those that assessed implicit bias towards doctors rather than patients, editorials, dissertations, letters to the editor and conference proceedings.

\section{RESULTS}

This article is protected by copyright. All rights reserved. 


\section{Articles Included in Review}

As outlined in Figure 1, 412 different articles were identified through a systematic literature search with five additional studies identified via other methods. Nineteen articles were assessed for full-text eligibility with ten articles meeting all criteria. Two articles were systematic reviews which were not included in the quantitative analysis outlined in Table 1. Additionally, two pairs of articles used the same data so were combined in this analysis. Only two datasets included ED doctors in isolation ${ }^{22-24}$, with the majority of studies including other specialties in their analysis. One dataset only included paediatricians but was included due to the use of emergency clinical vignettes ${ }^{25,26}$.

\section{Implicit Racial Bias Among Emergency Doctors}

All studies used the implicit association test (IAT), a tool developed by Harvard University which requires individuals to sort words into appropriate categories without time to elicit conscious thought ${ }^{1}$. It is thought to detect implicit bias if preconceived stereotypes become apparent in the pairing process. For example, in the Race IAT individuals may make associations with darker-skinned faces and negative words as a result of implicit racial bias. This test has been widely utilised ${ }^{1,27}$ and is based on cognitive priming and automatic activation of unconscious thoughts and attitudes ${ }^{28}$. The IAT is reported to have reliable construct validity in African American groups ${ }^{29}$, but no validation studies have yet been performed for its use in Indigenous Australians. However, the results from a large Australian study of 11,099 participants assessing implicit bias against Indigenous Australians ${ }^{30}$ yielded similar IAT results to a large American study of 404,277 participants $^{31}$.

Implicit bias was quantified in all studies using D-scores ${ }^{32}$. The majority of the studies we analysed found a moderate implicit preference for those with Caucasian appearance on the race-IAT ${ }^{22-24,32-34}$, with 
one dataset finding a minor implicit preference ${ }^{25,26}$. It should be noted that one study used a novel IAT which used American Indian faces ${ }^{22}$, however this IAT has not yet been validated.

Some studies performed additional IATs to assess other biases that may be present in the ED. One study found a minor implicit preference to Caucasians in a race cooperativeness IAT and in a race cooperativeness in medical procedures ${ }^{33}$. Similarly, another study found a minor implicit preference in a novel race-medical compliance IAT, however this IAT was not validated. Another study found a strong implicit preference for individuals with a higher socio-economic status ${ }^{32}$. Finally, one study found an increase in IAT scores from 0.50 (95\% CI, SD=0.34) to 0.55 (95\% CI, SD=0.39) in participants who completed the IAT post-ED shift. This study also reported an increase of 0.09 (95\% CI, $d=0.24)$ in those who worked busy or overcrowded shifts and an increase of 0.17 (95\% CI, d=0.47) in those who cared for 10 or more patients during their ED shift ${ }^{23}$.

\section{Association Between Implicit Bias and Clinical Decision-Making}

All studies that sought to seek a relationship between implicit bias and clinical decision-making used clinical vignettes. These required physicians to make judgements that related to acute trauma ${ }^{32}$ and emergency care including appropriate pain management $22,25,26,33$, recommendations for thrombolysis ${ }^{33}$ and asthma care ${ }^{25,26}$. For each vignette, a different race was used with one study using validated computer software to create facial expressions of pain ${ }^{34}$. One study demonstrated a significant association between implicit racial bias and clinical decision-making with higher IAT scores associated with a decreased likelihood to recommend thrombolysis for darker-skinned patients ${ }^{33}$. Another study demonstrated that higher IAT scores were associated with a decreased likelihood of prescribing narcotics to African American 
patients $^{25,26}$. The remaining five studies demonstrated no significant association between implicit bias and clinical decision-making.

\section{Study Limitations}

There were limitations of the selected studies in regards to sample size as the largest sample included 287 participants ${ }^{33}$, and in two datasets there were less than 100 participants $^{23-26}$. Only two datasets solely included ED healthcare workers ${ }^{22-24}$ and these populations may not accurately reflect the ED workforce. One paper acknowledged that inexperienced junior medical staff may not be analogous to senior clinicians and this may not accurately represent the clinicians who make treatment decisions ${ }^{33}$. Five studies only acquired data from a single site ${ }^{23-26,32}$. Comparability across studies is difficult due to known confounding variables of clinical education and experience, with only one study adequately controlling for confounding variables ${ }^{33}$.

Assessing clinical judgement based on isolated decisions creates an artificial vacuum, making these studies fundamentally flawed and extrapolation to real life clinical decision-making problematic. It fails to recognise individual patient characteristics, dynamic interactions and institutional context factors that may lead a clinician to make certain management decisions. The use of clinical vignettes may not accurately reflect the decisions made in the ED where physician fatigue, patient burden, time pressures and lack of clinical information may result in prejudiced patient management ${ }^{2,11}$. Clinical vignettes may also be prone to response bias, where participants provide a more socially desirable response than what they would do in clinical practice ${ }^{32}$. Finally, selection bias is likely in many of the studies in which the participants were selfselected and it is likely those clinicians with stronger implicit or explicit biases were excluded. 


\section{DISCUSSION}

All the included studies found some degree of implicit racial bias among emergency physicians, with five studies finding a moderate implicit preference towards Caucasians. However, only two studies showed a relationship with clinical decision-making. This data suggests that implicit racial bias exists among emergency doctors, but further interrogation into the effects of this on patient health outcomes including the patient perspective is necessary.

\section{Implicit Bias Leads to Stereotyping and Cognitive Shortcuts}

The ED lacks established provider-patient relationships resulting in increased reliance on cognitive shortcuts $^{22}$, heuristic thinking and premature diagnostic closure. Consequently, automatic activation of racial stereotypes ${ }^{13}$ may occur to a greater degree. Previous studies have linked higher IAT scores with poor patient communication, clinical verbal dominance, non-verbal cues and lower levels of patient centred dialogue $\mathrm{e}^{35,26}$. This may lead to absence of patient centred care and discriminatory clinical decision-making.

\section{The Role of Implicit Bias in Racial Disparities}

Healthcare disparities among racial and ethnic minorities have been widely documented. A recent scoping review by Owens et al, revealed that minority groups had less acute triage scores, longer waiting times and were less likely to receive analgesia ${ }^{37}$. Furthermore, there were increased rates of Left Without Being Seen (LWBS) and Leaving Against Medical Advice (LAMA) among Indigenous minority groups globally ${ }^{37}$. Aboriginal and Torres Strait Islander peoples are two and a half times more likely to have leave events compared to non-Indigenous Australians ${ }^{38}$. Leave events are associated with frequent representations to ED, delays in receiving adequate medical care and increased morbidity and mortality ${ }^{38}$. 
Negative experiences, distrust of medical professionals, stereotyping and racism are among the factors contributing to leave events for Aboriginal and Torres Strait Islander peoples ${ }^{38}$.

It is unequivocable that many factors play a role in these persisting healthcare disparities. Exploring all of these factors is out of the scope of this review, however it is important to note that individual, institutional and systemic factors play a significant part. Although generational effects have reduced the magnitude of overt racism, biases remain entrenched in healthcare institutions. This is in the form of institutional racism that involves unjust policies, values and practices which discriminate against racial minorities $^{39}$. Institutional racism may result in stereotype activation ${ }^{27}$ and differential treatment of minority groups by healthcare providers ${ }^{36}$ in the form of interpersonal bias. This may manifest in the form of explicit or implicit bias and has the potential to undermine the provider-patient relationship ${ }^{40}$. The different forms of racism are further defined in table 2.

In the studies we examined there was a lack of investigation into patient perception of quality of care, patient experiences of discrimination ${ }^{41}$ and longer-term health outcomes. Perceived discrimination has implications for both physical and psychological health outcomes for racial minorities, with higher rates of psychological distress, mental health diagnoses, early substance use, hypertension and low birth weight ${ }^{42}$. Furthermore, it may contribute to distrust of medical professionals ${ }^{35-37}$ resulting in higher rates of leave events and hinder racial minorities from seeking care or following treatment recommendations ${ }^{36}$. Vicarious discrimination may also impact the relationship that the individual's family and community have with the healthcare system ${ }^{42}$.

\section{Implicit Bias \& Racial Disparities in Australia}

This article is protected by copyright. All rights reserved. 
Indigenous communities continue to suffer adverse experiences in healthcare, which can be partly attributed to ongoing institutional racism ${ }^{5}$, and reinforced by structural inequities in housing, education, employment and incarceration ${ }^{5}$. Indigenous peoples are less likely to access appropriate care and often receive lower quality care ${ }^{2,5}$. Although there are currently no existing studies looking at implicit bias of healthcare workers towards Indigenous Australians, one study found most Australians carry an implicit bias towards Aboriginal and Torres Strait Islander peoples ${ }^{30}$. We chose to discuss the implications that social disadvantage and racism plays in Australia using case-studies in order to provide more meaningful context.

The fatal repercussions of institutionalised racism are shown in the case of Ms Dhu, who received inadequate healthcare and inhumane treatment by police officers ${ }^{9}$. Shortfalls in her medical care included a lower acuity triage score than clinically indicated and 'premature diagnostic closure' as a result of preconceived assumptions that her pain was 'exaggerated' and the product of 'behavioural gain'9. Similarly, racial stereotyping was a prominent feature of the coronial inquest of Naomi Williams, in which doctors presumed her chronic gastrointestinal symptoms were the result of drug use without adequate investigations or appropriate referral to explore other differentials ${ }^{7}$. The lack of escalation of care in Williams repeated presentations was similar to young Charlie Gowa, who presented to the ED on six consecutive days before receiving intensified treatment for melioidosis ${ }^{8}$. Finally, there was poor documentation and lack of timely investigations in all three cases $^{7-9}$.

These Coronial reports suggest that implicit racial bias may have contributed to the clinical decisionmaking of the nurses and doctors involved in these $\operatorname{cases}^{7-9}$, with significant racial stereotyping and reliance on pattern-recognition to formulate diagnoses. These cases were all in regional under-resourced communities, with Gowa's case being the most significant in terms of remoteness ${ }^{7-9}$. Together with the lack 
of clinical information this has been shown to result in implicit racial bias ${ }^{11}$. Due to the retrospective nature of these cases we are unable to make any accurate conclusions about patient perceptions of discrimination, however it was indicated that Naomi was dissatisfied with her care prior to her death ${ }^{7}$. Similarly, the family of Charlie Gowa were clearly distressed and frustrated with the inadequate care received from Bamaga Hospital $^{8}$.

\section{Addressing Implicit Bias and Racial Disparities}

Cultural competency training has already been implemented at various levels of medical training in Australia, however some have criticised that this training fails to recognise and address the structural causes of healthcare inequities ${ }^{2,43}$. Although addition of implicit bias education could help improve quality of care for racial minorities ${ }^{44}$, these biases are engrained into healthcare institutions and societal structures $^{40}$. Closing the gap of healthcare disparities thus requires a multi-faceted approach consisting of physician education, organisational policy changes that promote equity ${ }^{45}$ and structural changes such as rectification of inadequate housing, access to mental health services ${ }^{2}$ and lack of Indigenous/People of Colour employed in the health sector ${ }^{46}$. Australasian College for Emergency Medicine (ACEM) has a Reconciliation Action Plan (RAP) that includes compulsory online cultural competency training modules and a commitment to recruiting Indigenous trainees and building relationships with the Indigenous community ${ }^{47}$.

Another criticism of cultural competency training in Australia is that it may be tokenistic and oneoff training is insufficient ${ }^{5,9}$. Emergency trainees should be encouraged to complete placements in Aboriginal community-controlled health services where they can obtain a deeper understanding of Indigenous health ${ }^{5}$. Aboriginal community-controlled health services have proven to provide more 
equitable, higher-quality care to Indigenous Australians ${ }^{6}$. It would also provide opportunity to establish meaningful patient-provider relationships that challenges any pre-conceived biases or assumptions, both conscious and unconscious, about Aboriginal and Torres Strait Islander people ${ }^{48}$.

Individual physicians are not inherently at fault for their implicit bias, nor should blame be placed against individuals. However, physicians do have a responsibility to be aware of and actively engaged in efforts to reduce racial disparities in healthcare. Mainstream health services should also assume responsibility for these persisting disparities and should not solely place the onus on Aboriginal health services ${ }^{5}$. Healthcare organisations should examine policies and power paradigms that disproportionally disadvantage Indigenous Australians ${ }^{39}$ and should endeavour to provide equity-orientated healthcare ${ }^{2}$.

Specific strategies proposed to circumvent implicit bias includes bringing attention and awareness to such biases including non-verbal behaviours that may be perceived as discriminatory ${ }^{49}$. Once attention is drawn to these biases, physicians must acknowledge and challenge any discriminatory values, assumptions or stereotypes they possess towards racial minorities ${ }^{2}$. This involves self-reflection in everyday practice to attain a more nuanced understanding of their own racial bias and the potential impacts these may have on their patients ${ }^{5}$. Elimination of stereotyping of Indigenous Australians may be aided by exposure to counter-stereotypes by establishing meaningful relationships ${ }^{49,50}$ and promoting greater intercultural understanding ${ }^{50}$. These approaches should avoid pathologising Aboriginal and Torres Strait Islanders ${ }^{48}$ or placing blame on individuals of this marginalised group.

\section{Literature Gaps \& Avenues for Future Research}


As we have alluded to, there are significant literature gaps in this research area. Currently there are no studies assessing the impact of implicit bias on actual provider-patient interactions in the ED setting. A comprehensive study that includes different ED personnel from multiple institutions and assesses other measures of quality of care, including patient perceptions of physician bias, would be very valuable. Furthermore, a longitudinal study of implicit bias would be useful to assess longer term health outcomes, including chronic psychological stressors resulting from racial discrimination ${ }^{42}$.

We were unable to find any studies assessing implicit bias of ED doctors towards Aboriginal and Torres Strait Islander people, and our ability to generalise the results from international literature was limited. The Australian cases studies we examined indicate the importance of further research to include an investigation of implicit bias in regional/low resource settings and in cases that may be prone to more clinical ambiguity. Another important area for further literature to explore is implicit bias against Indigenous healthcare workers.

\section{Limitations to our study}

We recognise that our review had several limitations. Firstly, it is possible that we inadvertently excluded other studies utilising emergency vignettes or that included a subset of ED doctors in a larger cohort. Secondly, we only included studies that included a formal measurement of implicit bias.

\section{CONCLUSION}

It is evident that implicit racial bias exists among ED physicians, however the subsequent effects on patient outcomes has not been interrogated sufficiently in existing literature. Despite this, it is undeniable that interpersonal and institutional racism contributes to persisting healthcare disparities among racial 
minorities. This is highlighted through Australian case-studies, whereby racial stereotyping and preconceived presumptions contributed to fatal consequences for the Aboriginal and Torres Strait Islander community.

\section{REFERENCES}

1. Dehon E, Weiss N, Jones J, Faulconer W, Hinton E, Sterling S. A Systematic Review of the Impact of Physician Implicit Racial Bias on Clinical Decision Making. Academic Emergency Medicine. 2017 Aug;24(8):895-904.

2. Varcoe C, Bungay V, Browne AJ, Wilson E, Nadine Wathen C, Kolar K, et al. EQUIP Emergency: Study protocol for an organizational intervention to promote equity in health care. BMC Health Services Research. 2019 Oct 10;19(1):687.

3. Australian Bureau of Statistics. Estimates of Aboriginal and Torres Strait Islander Australians, 2016 [Internet]. Canberra (ACT): Commonwealth of Australia; 2018 [cited 2020 Aug 3]. Report no.:

3238.0.55.001. Available from: https://www.abs.gov.au/statistics/people/aboriginal-and-torres-straitislander-peoples/estimates-aboriginal-and-torres-strait-islander-australians/latest-release

4. Emergency department care 2017-18: Australian hopsital statistics. Canberra (ACT): Australian Institute of Health and Welfare; 2018. 96 p. Report no.: Health Services Series 89.

5. Durey A, Thompson SC. Reducing the health disparities of Indigenous Australians: time to change focus. BMC Health Services Research. 2012 Jun 10;12:151.

6. Gadsden T, Wilson G, Totterdell J, Willis J, Gupta A, Chong A, et al. Can a continuous quality improvement program create culturally safe emergency departments for Aboriginal people in Australia? A multiple baseline study. BMC Health Services Research. 2019 Apr 11;19(1):222.

This article is protected by copyright. All rights reserved. 
7. Grahame M. Inquest into the death of Naomi Williams. Tumut Local Court (NSW): State Coroner's Court of New South Wales; 2019. 58 p. Report no.: 2016/2569.

8. Brown, A. Review into the quality of health services provided by Bamaga Hospital. Brisbane (QLD): Office of the Health Ombudsman; 2020. 108 p.

9. Fogliani, R. Inquest into the death of Julieka Ivanna Dhu, 2015-16. Perth Coroners Court (WA): Western Australian Coroner’s Court; 2016. 165 p. Report no.: 11020-14

10. Hall WJ, Chapman MV, Lee KM, Merino YM, Thomas TW, Payne BK, et al. Implicit Racial/Ethnic Bias Among Health Care Professionals and Its Influence on Health Care Outcomes: A Systematic Review. American Journal of Public Health. 2015 Dec;105(12):60-76.

11. Zeidan AJ, Khatri UG, Aysola J, Shofer FS, Mamtani M, Scott KR, et al. Implicit Bias Education and Emergency Medicine Training: Step One? Awareness. Aem Education \& Training. 2019 Jan;3(1):8112. Marcelin JR, Siraj DS, Victor R, Kotadia S, Maldonado YA. The Impact of Unconscious Bias in Healthcare: How to Recognize and Mitigate It. Journal of Infectious Diseases. 2019 Aug 20;220(2):62-7

13. Chapman EN, Kaatz A, Carnes M. Physicians and implicit bias: how doctors may unwittingly perpetuate health care disparities. Journal of General Internal Medicine. 2013 Nov;28(11):1504-10.

14. Zook HG, Kharbanda AB, Flood A, Harmon B, Puumala SE, Payne NR. Racial Differences in Pediatric Emergency Department Triage Scores. Journal of Emergency Medicine. 2016 Feb 15;50(5):72015. Ali I, Vattigunta S, Jang JM, Hannan CV, Ahmed MS, Linton B, et al. Racial Disparities are Present in the Timing of Radiographic Assessment and Surgical Treatment of Hip Fractures. Clinical Orthopaedics \& Related Research. 2020 Mar;478(3):455-61.

16. Lopez D, Katzenellenbogen JM, Sanfilippo FM, Woods JA, Hobbs MS, Knuiman MW, et al. Disparities experienced by Aboriginal compared to non-Aboriginal metropolitan Western Australians in 
receiving coronary angiography following acute ischaemic heart disease: the impact of age and comorbidities. International Journal for Equity in Health. 2014 Oct 21;13(1):93.

17. Chiu AS, Jean RA, Davis KA, Pei KY. Impact of Race on the Surgical Management of Adhesive Small Bowel Obstruction. Journal of the American College of Surgeons. 2018 Jun;226(6):968-76.

18. Benzing AC, Bell C, Derazin M, Mack R, MacIntosh T. Disparities in Opioid Pain Management for Long Bone Fractures. J Racial Ethn Health Disparities. 2020 May 7;7(4):740-5.

19. Trout MJ, Henson G, Senthuran S. Characteristics and outcomes of critically ill Aboriginal and/or Torres Strait Islander patients in North Queensland. Anaesthesia and Intensive Care. 2015 Mar 1;43(2):21620. Priest N, Truong M, Chong S, Paradies Y, King TL, Kavanagh A, et al. Experiences of racial discrimination and cardiometabolic risk among Australian children. Brain Behavior and Immunity. 2020 Jul;87:660-5.

21. Closing the Gap Report 2020. Canberra (ACT): Department of the Prime Minister and Cabinet; 2020. 108 p.

22. Puumala SE, Burgess KM, Kharbanda AB, Zook HG, Castille DM, Pickner WJ, et al. The Role of Bias by Emergency Department Providers in Care for American Indian Children. Medical Care. 2016 Jun;54(6):562-

23. Johnson TJ, Hickey RW, Switzer GE, Miller E, Winger DG, Nguyen M, et al. The Impact of Cognitive Stressors in the Emergency Department on Physician Implicit Racial Bias. Academic Emergency Medicine. 2016 Mar;23(3):297-305.

24. Johnson TJ, Winger DG, Hickey RW, Switzer GE, Miller E, Nguyen MB, et al. Comparison of Physician Implicit Racial Bias Toward Adults Versus Children. Academic Pediatrics. 2017 Mar;17(2):120- 
25. Sabin JA, Greenwald AG. The influence of implicit bias on treatment recommendations for 4 common pediatric conditions: pain, urinary tract infection, attention deficit hyperactivity disorder, and asthma. American Journal of Public Health. 2012 May;102(5):988-95.

26. Sabin JA, Rivara FP, Greenwald AG. Physician implicit attitudes and stereotypes about race and quality of medical care. Medical Care. 2008 Jul;46(7):678-85.

27. Maina I, Belton T, Ginzberg S, Singh A, Johnson T. A decade of studying implicit racial/ethnic bias in healthcare providers using the implicit association test. Social Sciences and Medicine. 2018 Feb; 199: 219-229.

28. Greenwald AG, McGhee DE, Schwartz JL. Measuring individual differences in implicit cognition: the implicit association test. Journal of Personality \& Social Psychology. 1998 Jun;74(6):1464-80.

29. Kurdi B, Seitchik AE, Axt JR, Carroll TJ, Karapetyan A, Kaushik N, et al. Relationship between the Implicit Association Test and intergroup behavior: A meta-analysis. American Psychologist. 2019 Jul;74(5):569-86.

30. Shirodkar S. Bias against Indigenous Australians: Implicit Association Test results for Australia. Journal of Australian Indigenous Issues. 2020 Dec;22(3-4):3-34.

31. Sabin J, Nosek BA, Greenwald A, Rivara FP. Physician’s implicit and explicit attitutdes about race by MD race, ethnicity and gender. J Health Care Poor Undeserved. 2009 Apr 6;20(3):896-913.

32. Haider AH, Schneider EB, Sriram N, Dossick DS, Scott VK, Swoboda SM, et al. Unconscious race and social class bias among acute care surgical clinicians and clinical treatment decisions. JAMA Surgery. 2015 May;150(5):457-64.

33. Green AR, Carney DR, Pallin DJ, Ngo LH, Raymond KL, Iezzoni LI, et al. Implicit bias among physicians and its prediction of thrombolysis decisions for black and white patients. Journal of General Internal Medicine. 2007 Jun 27;22(9):1231-8. 
34. Hirsh AT, Hollingshead NA, Ashburn-Nardo L, Kroenke K. The interaction of patient race, provider bias, and clinical ambiguity on pain management decisions. Journal of Pain. 2015 Jun 1;16(6):558-

35. Cooper LA, Roter DL, Carson KA, Beach MC, Sabin JA, Greenwald AG, et al. The associations of clinicians' implicit attitudes about race with medical visit communication and patient ratings of interpersonal care. American Journal of Public Health. 2012 May;102(5):979-87.

36. Dovidio JF, Penner LA, Albrecht TL, Norton WE, Gaertner SL, Shelton JN. Disparities and distrust: the implications of psychological processes for understanding racial disparities in health and health care. Social Science \& Medicine. 2008 Aug;67(3):478-86.

37. Owens A, Holroyd BR, McLane P. Patient race, ethnicity, and care in the emergency department: A scoping review. Canadian Journal of Emergency Medical Care. 2020 Mar;22(2):245-53.

38. Understanding leave events for Aboriginal and Torres Strait Islander peoples and other Australians from health service organisations: A Systematic Literature Review. Sydney (NSW): Australian Commission on Safety and Quality in Health care; 2020. 38 p.

39. Bourke CJ, Marrie H, Marrie A. Transforming institutional racism at an Australian hospital. Australian Health Review. 2019 Jan;43(6):611-618.

40. Cobbinah SS, Lewis J. Racism \& Health: A public health perspective on racial discrimination. Journal of Evaluation in Clinical Practice. 2018 Mar 6;24(5):995-8.

41. Johnson RL, Saha S, Arbelaez JJ, Beach MC, Cooper LA. Racial and ethnic differences in patient perceptions of bias and cultural competence in health care. Journal of General Internal Medicine. 2004 Feb;19(2):101-10.

42. Williams DR, Neighbors HW, Jackson JS. Racial/ethnic discrimination and health: findings from community studies. American Journal of Public Health. 2008 Sep;98(9):29-37. 
43. Downing R, Kowal E, Paradies Y. Indigenous cultural training for health workers in Australia. International Journal for Quality in Health Care. 2011 Jun;23(3):247-57.

44. Oliver MN, Wells KM, Joy-Gaba JA, Hawkins CB, Nosek BA. Do physicians' implicit views of African Americans affect clinical decision making? Journal of the American Board of Family Medicine. 2014 Apr;27(2):177-88.

45. Nazroo JY, Bhui KS, Rhodes J. Where next for understanding race/ethnic inequalities in severe mental illness? Structural, interpersonal and institutional racism. Sociology of Health \& Illness. 2020 Sep;42(2):262-76.

46. Heron S, Lovell EO, Wang E, Bowman SH. Promoting diversity in emergency Medicine:Summary recommendations from the 2008 Council of Emergency Medicine Residency Directors (CORD) Academic Assembly Diversity workgroup. Academic Emergency Medicine. 2009 Mar 26;16(5):450-3.

47. Australasian College for Emergency Medicine Innovate Reconciliation Action Plan. West Melbourne (VIC): Australasian College for Emergency Medicine. 2018. 13 p.

48. Askew DA, Lyall VJ, Ewen SC, Paul D, Wheeler M. Understanding practitioner professionalism in Aboriginal and Torres Strait Islander health: lessons from student and registrar placements at an urban Aboriginal and Torres Strait Islander primary healthcare service. Australian Journal of Primary Health. 2017 Oct;23(5):446-50.

49. Stone J, Moskowitz GB. Non-conscious bias in medical decision making: what can be done to reduce it? Medical Education. 2011 Aug;45(8):768-76

50. Paradies Y, Truong M, Priest N. A systematic review of the extent and measurement of healthcare provider racism. Journal of General Internal Medicine. 2014 Feb;29(2):364-87.

This article is protected by copyright. All rights reserved. 


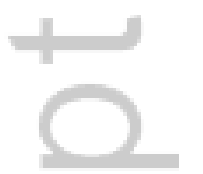

4 
Table 1: Data Extraction Table

\begin{tabular}{|c|c|c|c|c|c|c|c|}
\hline Source & Population & Research question & Intervention & Mean IAT D score* & $\begin{array}{l}\text { Association of implicit } \\
\text { bias with clinical } \\
\text { decision-making }\end{array}$ & Limitations & Strengths \\
\hline $\begin{array}{l}\text { Green et al., } \\
2007\end{array}$ & $\begin{array}{l}\mathrm{N}=287 \text { Internal } \\
\text { Medicine and EM } \\
\text { residents }\end{array}$ & $\begin{array}{l}\text { To assess whether } \\
\text { implicit racial bias } \\
\text { influenced a } \\
\text { physician's decision } \\
\text { to recommend } \\
\text { thrombolysis }\end{array}$ & $\begin{array}{l}\text { Clinical vignette of } \\
\text { patient presenting to } \\
\text { ED with features of } \\
\text { acute myocardial } \\
\text { infarction (AMI) }\end{array}$ & $\begin{array}{l}\text { Race IAT }=0.36(\mathrm{SD}=0.40, \mathrm{p}< \\
0.001) \\
\text { Race cooperativeness }=0.30(\mathrm{SD}= \\
0.39, \mathrm{p}<0.001) \\
\text { Race cooperativeness in medical } \\
\text { procedures }=0.22(\mathrm{SD}=0.40, \mathrm{p}< \\
0.001)\end{array}$ & $\begin{array}{l}\text { Implicit racial bias } \\
\text { influenced the decision } \\
\text { to recommend } \\
\text { thrombolysis for AMI }\end{array}$ & $\begin{array}{l}\text { May not be representative of the } \\
\text { clinicians who would normally } \\
\text { make thrombolysis decisions } \\
\text { - Clinical vignette may not } \\
\text { accurately represent real life } \\
\text { clinical decision-making }\end{array}$ & $\begin{array}{l}\text { - } \\
\text { confults adjusted for } \\
\text { as physician race, sex, } \\
\text { socioeconomic background, } \\
\text { explicit race bias and belief } \\
\text { of effectiveness of } \\
\text { thrombolysis }\end{array}$ \\
\hline $\begin{array}{l}\text { Haider et al., } \\
2015\end{array}$ & $\begin{array}{l}\mathrm{N}=230 \text { attending } \\
\text { physicians, } \\
\text { fellows and } \\
\text { residents from a } \\
\text { range of } \\
\text { specialties } \\
\text { (surgery, } \\
\text { anaesthesia, ED, } \\
\text { critical care) }\end{array}$ & $\begin{array}{l}\text { To determine } \\
\text { whether clinician's } \\
\text { unconscious race } \\
\text { and/or social class } \\
\text { biases correlate with } \\
\text { patient management } \\
\text { decisions }\end{array}$ & $\begin{array}{l}\text { Eight clinical } \\
\text { vignettes relating to } \\
\text { acute trauma and } \\
\text { surgery }\end{array}$ & $\begin{array}{l}\text { Race IAT }=0.42(95 \% \mathrm{CI}=0.37- \\
0.48, \mathrm{p}<0.05) \\
\text { Social class IAT }=0.71(95 \% \mathrm{CI}= \\
0.65-0.78, \mathrm{p}<0.05)\end{array}$ & $\begin{array}{l}\text { No significant } \\
\text { association between IAT } \\
\text { scores and clinical } \\
\text { decision-making }\end{array}$ & $\begin{array}{l}\text { - } \quad \text { Clinical vignette may not } \\
\text { accurately represent real life } \\
\text { clinical decision-making } \\
\text { - } \quad \text { Single site }\end{array}$ & \\
\hline $\begin{array}{l}\text { Hirsh et al., } \\
2015\end{array}$ & $\begin{array}{l}\mathrm{N}=129 \text { residents } \\
\text { and fellows from } \\
\text { a range of } \\
\text { specialties } \\
\text { including ED }\end{array}$ & $\begin{array}{l}\text { To determine } \\
\text { whether implicit } \\
\text { racial bias affects } \\
\text { pain management } \\
\text { decisions }\end{array}$ & $\begin{array}{l}\text { Twelve clinical } \\
\text { vignettes relating to } \\
\text { pain management } \\
\text { decisions }\end{array}$ & $\begin{array}{l}\text { Race IAT }=0.5(\mathrm{SD}=0.42, \mathrm{p}< \\
0.001)\end{array}$ & $\begin{array}{l}\text { No significant } \\
\text { association between IAT } \\
\text { scores and clinical } \\
\text { decision-making }\end{array}$ & $\begin{array}{l}\text { - Confounding variables were not } \\
\text { controlled (e.g. explicit biases } \\
\text { and provider opinion of } \\
\text { prescription of opioid vs non- } \\
\text { opioid analgesia) }\end{array}$ & 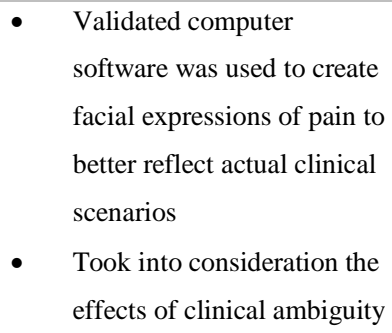 \\
\hline
\end{tabular}

This article is protected by copyright. All rights reserved. 


\begin{tabular}{|c|c|c|c|c|c|c|c|}
\hline $\begin{array}{l}\text { Johnson et } \\
\text { al., } 2016 \text { \& } \\
2017\end{array}$ & $\begin{array}{l}\mathrm{N}=91 \text { residents } \\
\text { working in a } \\
\text { paediatric ED }\end{array}$ & $\begin{array}{l}\text { To determine } \\
\text { whether levels of } \\
\text { implicit racial bias } \\
\text { are exacerbated } \\
\text { post-ED shift } \\
\text { Comparison of } \\
\text { implicit racial } \\
\text { biases towards } \\
\text { adults versus } \\
\text { children among } \\
\text { resident physicians }\end{array}$ & $\begin{array}{l}\text { Race IAT performed } \\
\text { pre or post ED shift }\end{array}$ & $\begin{array}{l}\text { Pre-shift race IAT = } 0.50(\mathrm{SD}=0.34 \text {, } \\
\mathrm{p}<0.05) \\
\text { Post-shift race IAT }=0.55(\mathrm{SD}= \\
0.39, \mathrm{p}<0.05) \\
\text { Mean increase of } 0.09 \text { ( } 95 \% \mathrm{CI}, \\
\mathrm{d}=0.24 \text { ) among those who worked } \\
\text { ED shifts that were busy or } \\
\text { overcrowded } \\
\text { Mean increase of } 0.17 \text { ( } 95 \% \mathrm{CI}, \\
\mathrm{d}=0.47) \text { among those who cared for } \\
10 \text { or more patients during their ED } \\
\text { shift }\end{array}$ & N/A & $\begin{array}{ll}\text { - } & \text { Small sample size } \\
\text { - } & \text { Single site } \\
\text { - } & \text { Did not enrol physicians } \\
\text { - } & \text { Porking an overnight ED shift } \\
& \text { IAT pre-shift were not matched } \\
\text { with those who completed the } \\
\text { IAT post-shift according to race, } \\
\text { sex and other important } \\
\text { demographics }\end{array}$ & \\
\hline $\begin{array}{l}\text { Puumala et } \\
\text { al., } 2016\end{array}$ & $\begin{array}{l}\mathrm{N}=154 \\
\text { physicians, nurses } \\
\text { and advanced } \\
\text { practice providers } \\
\text { working in EDs }\end{array}$ & $\begin{array}{l}\text { To assess both } \\
\text { implicit and explicit } \\
\text { bias and their } \\
\text { relationship with } \\
\text { clinical care }\end{array}$ & $\begin{array}{l}\text { Four clinical vignettes } \\
\text { relating to asthma care } \\
\text { and pain management }\end{array}$ & $\begin{array}{l}\text { Race IAT }=0.53(95 \% \mathrm{CI}=0.40- \\
0.66, \mathrm{p}<0.05)\end{array}$ & $\begin{array}{l}\text { No significant } \\
\text { association between IAT } \\
\text { scores and clinical } \\
\text { decision-making }\end{array}$ & $\begin{array}{l}\text { - Confounding variables were not } \\
\text { controlled for (e.g. diversity } \\
\text { education of physicians, } \\
\text { socioeconomic status) } \\
\text { - } \quad \text { Novel race IAT not validated }\end{array}$ & $\begin{array}{l}\text { - } \quad \text { Five different EDs used in } \\
\text { sample }\end{array}$ \\
\hline $\begin{array}{l}\text { Sabin et al., } \\
2008 \text { \& } 2012\end{array}$ & $\begin{array}{l}\mathrm{N}=86 \\
\text { paediatricians }\end{array}$ & $\begin{array}{l}\text { To determine } \\
\text { whether there is an } \\
\text { association between } \\
\text { pro-white attitude, } \\
\text { racial stereotypes } \\
\text { and treatment } \\
\text { recommendations }\end{array}$ & $\begin{array}{l}\text { Four clinical vignettes } \\
\text { relating to paediatric } \\
\text { management of } \\
\text { asthma, UTI, ADHD } \\
\text { and pain }\end{array}$ & $\begin{array}{l}\text { Race IAT }=0.18(\mathrm{SD}=0.44, \mathrm{p}= \\
0.01) \\
\text { Race-medical compliance }=0.25(\mathrm{SD} \\
=0.42, \mathrm{p}=0.001)\end{array}$ & $\begin{array}{l}\text { Prescription of narcotics } \\
\text { for African American } \\
\text { patients were reduced in } \\
\text { those with a pro-white } \\
\text { bias on the IAT } \\
\text { No significant } \\
\text { correlation between } \\
\text { implicit bias and } \\
\text { treatment } \\
\text { recommendations for } \\
\text { UTI, ADHD or asthma }\end{array}$ & $\begin{array}{ll}\text { - } & \text { Small sample size } \\
\text { - } & \text { Single site } \\
\text { - } & \text { Medical compliance IAT not } \\
& \text { validated } \\
\text { - } & \text { Clinical vignettes may not } \\
& \text { accurately represent real life } \\
\text { clinical decision-making }\end{array}$ & \\
\hline
\end{tabular}

This article is protected by copyright. All rights reserved. 
Table 2: Forms of Racism

\begin{tabular}{|l|l|}
\hline Term & Definition \\
\hline Interpersonal racism & $\begin{array}{l}\text { Unfair treatment or discriminatory interactions } \\
\text { between individuals based on race which may } \\
\text { manifest as either derogatory or privileging } \\
\text { comments, attitudes or behaviours }\end{array}$ \\
\hline Institutional racism & $\begin{array}{l}\text { Institutional or organisational policies, values, } \\
\text { norms and practices that either disadvantage or } \\
\text { advantage members of particular races }\end{array}$ \\
\hline Structural racism & $\begin{array}{l}\text { Societal and government laws, policies, values, } \\
\text { norms and practices that create or maintain racial } \\
\text { disparities in access to resources, opportunities } \\
\text { and power }\end{array}$ \\
\hline
\end{tabular}

Figure 1: PRISMA diagram

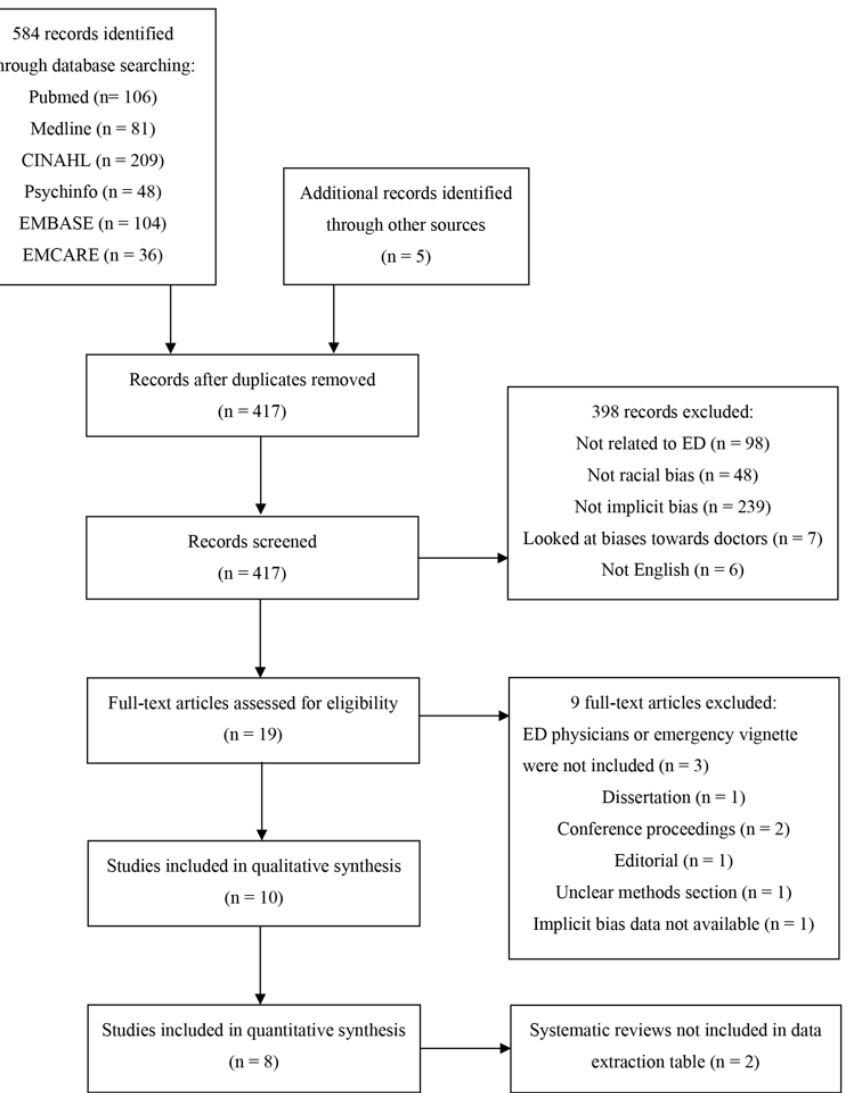


Appendix 1: Search strategy

\section{\# $\quad$ Searches}

Results

1 (implicit bias or unconscio?s bias).ab. or implicit bias.ti. or unconscio?s bias.ti. or unaware bias.ti.

2 *prejudice/ or exp racism/

x3 *"Attitude of Health Personnel"/eh [Ethnology]

*Emergencies/

exp *Emergency Service, Hospital/

12948

6 (emergency department* or ED).ab. or emergency department*.ti. or ED.ti. or emergency*.ti. or emergency*.ab.

$9 \quad 4$ or 5 or 6

10 2 or $7 \quad 121149$

$11 \quad 8$ and 9 and 10 


\section{University Library}

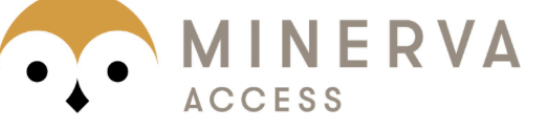

A gateway to Melbourne's research publications

Minerva Access is the Institutional Repository of The University of Melbourne

Author/s:

Quigley, A;Hutton, J;Phillips, G;Dreise, D;Mason, T;Garvey, G;Paradies, Y

Title:

Review article: Implicit bias towards Aboriginal and Torres Strait Islander patients within Australian emergency departments

Date:

2020-11-28

Citation:

Quigley, A., Hutton, J., Phillips, G., Dreise, D., Mason, T., Garvey, G. \& Paradies, Y. (2020). Review article: Implicit bias towards Aboriginal and Torres Strait Islander patients within Australian emergency departments. EMERGENCY MEDICINE AUSTRALASIA, 33 (1), pp.9-18. https://doi.org/10.1111/1742-6723.13691.

Persistent Link:

http://hdl.handle.net/11343/276660 